\title{
Climate and Hazardous Convective Weather
}

\author{
Michael K. Tippett • John T. Allen • \\ Vittorio A. Gensini · Harold E. Brooks
}

Published online: 28 February 2015

(C) The Author(s) 2015. This article is published with open access at Springerlink.com

\begin{abstract}
Substantial progress has been made recently relating the large-scale climate system and hazardous convective weather (HCW; tornadoes, hail, and damaging wind), particularly over the USA where there are large societal impacts and a long observational record. Despite observational data limitations, HCW has shown to be influenced by the climate system and the tropical atmosphere via the Madden-Julian Oscillation and El Niño-Southern Oscillation. Analysis of the atmospheric environments favorable to $\mathrm{HCW}$ (e.g., convective available potential energy and vertical wind shear) avoids observational and model limita-
\end{abstract}

This article is part of the Topical Collection on Extreme Events

M. K. Tippett $(\bowtie)$

Department of Applied Physics and Applied Mathematics, Columbia University,

New York, NY, USA

e-mail: tippett@iri.columbia.edu

\section{K. Tippett}

Center of Excellence for Climate Change Research, Department of Meteorology, King Abdulaziz University, Jeddah, Saudi Arabia

J. T. Allen

International Research Institute for Climate and Society

Columbia University,

Palisades, NY, USA

V. A. Gensini

Meteorology Program,

College of DuPage,

Glen Ellyn, IL, USA

H. E. Brooks

National Severe Storms Laboratory,

National Oceanic and Atmospheric Administration (NOAA),

Norman, OK 73072, USA tions. While few robust trends are seen over recent decades, future climate projections indicate increased frequency of such environments over the USA, Europe, and Australia, suggesting increased future $\mathrm{HCW}$ activity. A recent increase in the year-to-year variability of US tornado occurrence is striking, but not yet understood. Dynamical downscaling to convection-permitting resolutions promises improved understanding of the relationships between large-scale climate and $\mathrm{HCW}$ occurrence.

Keywords Severe thunderstorms - Climate variability Climate change $\cdot$ Tornadoes $\cdot$ Hail

\section{Introduction}

This paper reviews recent research on connections between large-scale climate signals and severe convective activity over land. By "climate signals," we refer to variability in the earth system characterized by time scales of weeks to centuries and spatial scales of several hundreds of kilometers or more. Notable climate signals include the MaddenJulian Oscillation (MJO), the El Niño-Southern Oscillation (ENSO), and radiatively forced climate change. Doswell [32] describes severe convection as "the variety of hazardous events produced by deep, moist convection." Here, we focus on tornadoes, hail, and damaging winds, and we refer to these events collectively as hazardous convective weather (HCW). Improved understanding of the role that climate signals play in modulating the frequency and intensity of HCW activity may lead to useful long-range outlooks (weeks to months) and projections (years to decades), which in turn may help society to better manage the risks from $\mathrm{HCW}$, including damage to property and loss of life [33, 83]. 
There are two outstanding difficulties in relating climate signals with HCW activity. The first is the lack of "climate quality" (i.e., multi-decade and homogeneous in time) HCW observational data sets comparable to those used to study precipitation and temperature extremes [50]. This issue is important and unavoidable, and we review the available observational data and their limitations in "Observations of Hazardous Convective Weather". Second, no dynamical models are currently able to adequately resolve both climate signals and severe convection, primarily due to the computational cost of representing the disparate spatial and time scales of HCW (minutes and tens of meters) and climate (decades and thousands of kilometers).

A substantial body of research directed at improving short-term HCW forecasting (e.g., Brooks et al. [12]) has led to a good understanding of the atmospheric environments (ingredients; Doswell et al. [34]) that are favorable to $\mathrm{HCW}$ occurrence. Forecasters are able to identify in advance broad regions where atmospheric conditions are favorable for $\mathrm{HCW}$, and today, most cases of severe weather in the USA occur in regions that have been identified as being at risk. For instance, $77 \%$ of all tornadoes and $88 \%$ of all significant tornadoes (EF2-EF5) in the USA in 2010 occurred in areas under active National Oceanic and Atmospheric Administration (NOAA) Storm Prediction Center (SPC) convective watches (Greg Carbin, personal communication). However, prediction of the intensity, type, timing, and precise location of HCW remains highly challenging. $\mathrm{HCW}$ is rare, and most often does not occur even when the atmospheric environment is favorable; this is the so-called initiation problem. Despite these limitations, the description of HCW favorable environments developed for short-term forecasting provides both a scientific basis and a practical approach for relating climate signals with severe convection. Rather than searching for climate signals solely in reports of HCW occurrence, these climate signals are identified in the frequency of favorable environments.

The structure of the paper is as follows: In "Observations of Hazardous Convective Weather", we discuss the available HCW observational data, including reports and remotely sensed data. Common characterizations of $\mathrm{HCW}$ favorable environments are described in "Environments Favorable to Hazardous Convective Weather". Contributions from the climate system to the seasonal variability are discussed, including the relationship to the annual cycle and sources of intraseasonal and intra-annual variability in "Annual Cycle" and "Seasonal and Intraseasonal Climate Variability". In "Observed Trends and Long-Term Variability", we consider the observed changes to the occurrence of severe thunderstorms in the late twentieth and early twenty-first centuries. In "Climate Change Projections", we examine the projections of severe convection for the late twenty-first century and describe the current understanding of how a warming climate will impact HCW occurrence. Finally, we discuss current limitations within the field and offer insight into areas of future development in understanding the interactions between the climate system and severe convection over land.

\section{Observations of Hazardous Convective Weather}

The usual station-based approach used for observations of temperature and precipitation is not useful for $\mathrm{HCW}$ because the size of the typical event is small relative to station density. The longest and most direct records of severe convective activity are based on eyewitness reports of HCW and subsequent assessment of damage. For instance, the SPC Severe Weather Database (SWD) is the primary source of the US severe weather occurrence information and contains tornado (1950 to the present), hail (1955 to the present), and wind (1955 to the present) reports updated on a yearly basis with data provided by local NWS offices [80]. Report data are dependent on observer availability and, therefore, have nonstationary features that are difficult to characterize. The number of US tornado reports more than doubles over the lifetime of the SPC SWD (see Fig. 1a), with most of this increase associated with weak tornadoes and believed to be non-meteorological in origin [93]. Likewise, there is a remarkable unexplained spike in the number of hail reports during the early 2000s (Fig. 1b). Changing intensity estimation procedures introduce additional inhomogeneities in the record [36]; note the downward shift in EF2+ values after the 1970s. The Fujita-Pearson scale (F scale; introduced in the early 1970s and adopted into official usage by the late 1970s) and its successor, the Enhanced Fujita Scale (EF scale; in use since February 2007), rate tornado intensity [(E)F0-(E)F5, weakest to strongest] based on damage assessment $[36,40]$. Tornadoes that occurred prior to the adoption of the $\mathrm{F}$ scale were rated retrospectively based on newspaper accounts $[36,65,80]$. Therefore, while the length of the SWD is adequate for climate applications, non-meteorological variability tends to obscure any climate-forced variability. In particular, the US database is too flawed to provide direct information about trends in HCW occurrence [55]. Some report statistics appear less affected by non-meteorological trends, e.g., tornado days (number of days with at least one tornado) and number of intense tornadoes (e.g., rated (E)F1 or (E)F2 and greater).

$\mathrm{HCW}$ report databases exist outside the USA, but are of insufficient length or quality for most climate analyses. The European Severe Weather Database (ESWD) includes reports of straight-line wind gusts, tornadoes (including waterspouts), large hail, heavy precipitation, 
Fig. 1 Annual number of CONUS a (E)F0+, (E)F1+, (E)F2+ tornado reports and tornado environment index (TEI) values (1950-2013; adapted from [87]), and $\mathbf{b}$ wind, hail, and hail greater than 2 in. reports (1955-2013)
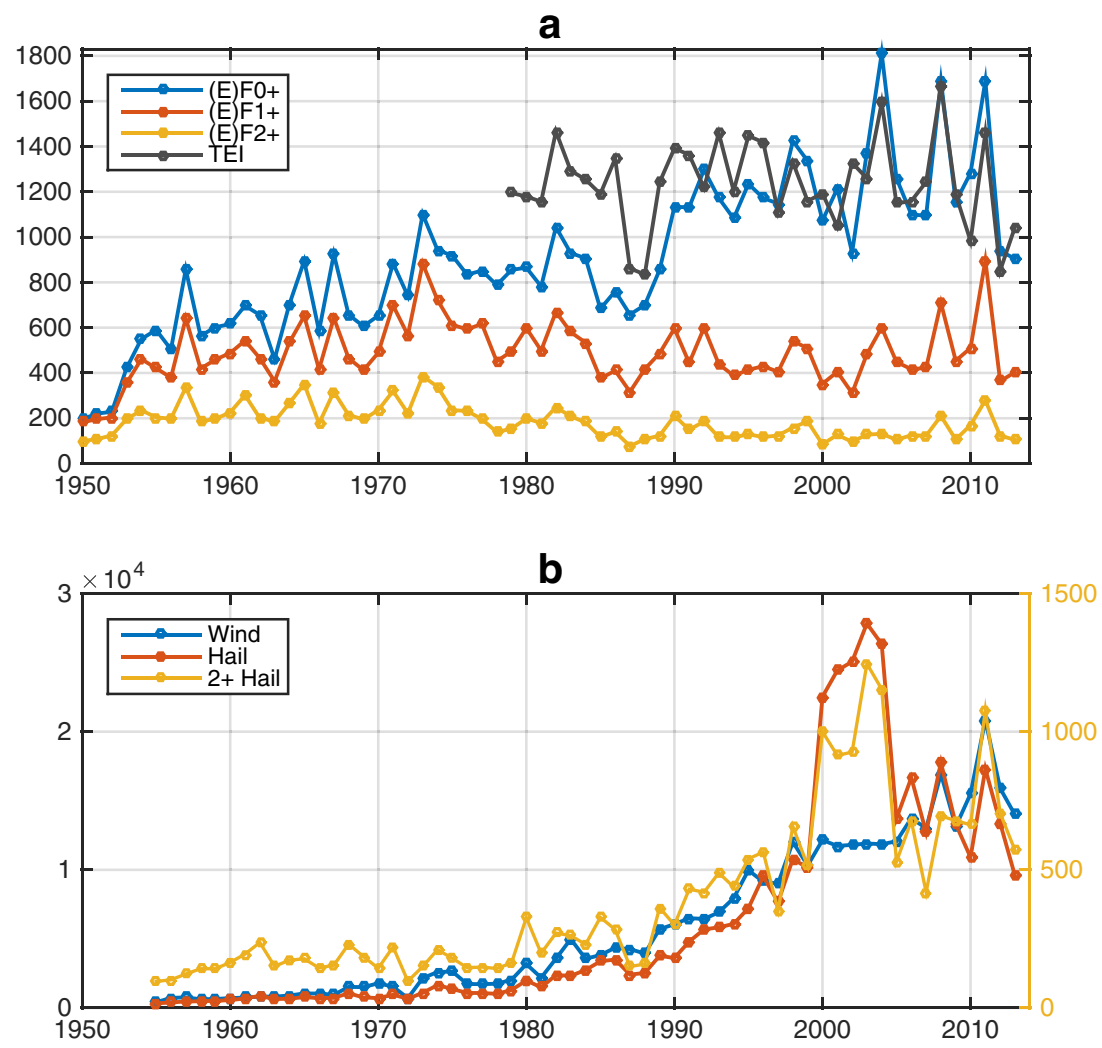

funnel clouds, gustnadoes, and lesser whirlwinds [37]. The ESWD contains contributions from many counties and is substantially less homogeneous in time and space than the SPC SWD [49]. Other national observational records of severe thunderstorms exist for Australia, China, and South Africa.

Hail pad networks (consisting typically of a few hundred hail pads arranged 1 per $15-25 \mathrm{~km}^{2}$ ) are a source of $\mathrm{HCW}$ data that does not require an observer to be present. However, these networks can be expensive and require laborious maintenance $[30,98]$. Hail pad networks are present in a number of countries including Spain, France, Argentina, Italy, Greece, and China [62, 77, 98]. Insurance loss data is also typically used to determine hail occurrence, with damage ranging from agricultural to structural. However, loss data is sensitive to population density, temporal changes in portfolios, and construction materials increasingly sensitive to hail impact $[22,56,78]$.

The limitations of in situ observations have prompted exploration of remote sensing for detecting and producing climatologies of $\mathrm{HCW}$, particularly over data-sparse regions outside the USA. Remote sensing does not provide direct measurements of $\mathrm{HCW}$, and current remote sensingderived records are too short for many climate applications. Nevertheless, remote sensing data sets show promise in providing spatially complete estimates of the area impacted by HCW. Three of the more promising avenues include satellite detection of overshooting convective cloud tops associated with severe hail $[8,21,71]$, radar reflectivity determined maximum expected size of hail [23], and ground-based sensor networks for lightning detection of positive cloud-toground strikes associated with HCW [54].

\section{Environments Favorable to Hazardous Convective Weather}

An alternative to analyzing the impact of climate signals on $\mathrm{HCW}$ events directly is to examine their impact on the frequency of HCW favorable environments. This approach is attractive since there are both representative long-term historical estimates (reanalysis) and climate model projections of these environments. A similar environment approach has been applied to the study of tropical cyclones genesis [42, 47, 48, 86] and used to study the impacts of ENSO, MJO, and climate change on tropical cyclone frequency [17-19]. A weakness of this approach is that environments only partially explain HCW occurrence (the initiation problem), and the fidelity of model environments is limited.

The ingredients for $\mathrm{HCW}$ can be broken down into three main types: vertical wind shear which contributes to the organization and longevity of severe convection, thermodynamic propensity for updraft development, and a process 
for convective initiation. The parameters most commonly used to describe the first two aspects are the bulk vertical wind shear between the surface and $6 \mathrm{~km}$ (S06) and convective available potential energy (CAPE). Other measures of vertical shear include storm relative helicity (SRH) and vertical shear between the surface and lower levels, e.g., S01 used in the tornado environment frequency (Fig. 2). Other thermodynamic parameters include convective inhibition, lapse rate, lifted condensation level, and convective precipitation. These parameters are sometimes examined individually or in combinations, as in the product of SRH and CAPE (the energy-helicity index, EHI; [26, 27]), the weighted product of CAPE and S06 [2, 14], and the weighted product of the monthly averaged SRH and convective precipitation (tornado environment index, TEI; Tippett et al. [87]). Convective initiation is more difficult to characterize and typically neglected. In a model setting, Trapp et al. [90] used occurrence of convective precipitation as proxy for initiation. Although most studies have used instantaneous or 6-h environmental data, monthly averages have recently been shown to capture shifts in the distribution of favorable environments [5, 85, 87]. For example, the TEI is calibrated to match the monthly climatology (1979-2010) of US tornado occurrence and captures some interannual variability of annual CONUS totals (see Fig. 1a), as well as monthly and regional variability.

\section{Annual Cycle}

The annual cycle is arguably the largest forced signal in the climate system, and its modulation of HCW activity in the USA is exceptionally clear $[13,35]$. The annual cycle provides a useful opportunity to assess the degree to which HCW favorable environments and models are able to explain annual cycle variations in $\mathrm{HCW}$ reports. Brooks et al. [15] computed the annual cycle of severe convection parameters from global reanalysis in several locations in the USA and Europe, finding regional variations in seasonality generally consistent with that of HCW occurrence. Gensini and Ashley [44] computed severe convection parameters for the USA from a high-resolution regional reanalysis and presented the spatial variation of their annual cycle. Tippett et al. [87] directly compared the TEI annual cycle with that of CONUS tornado reports and found reasonable agreement

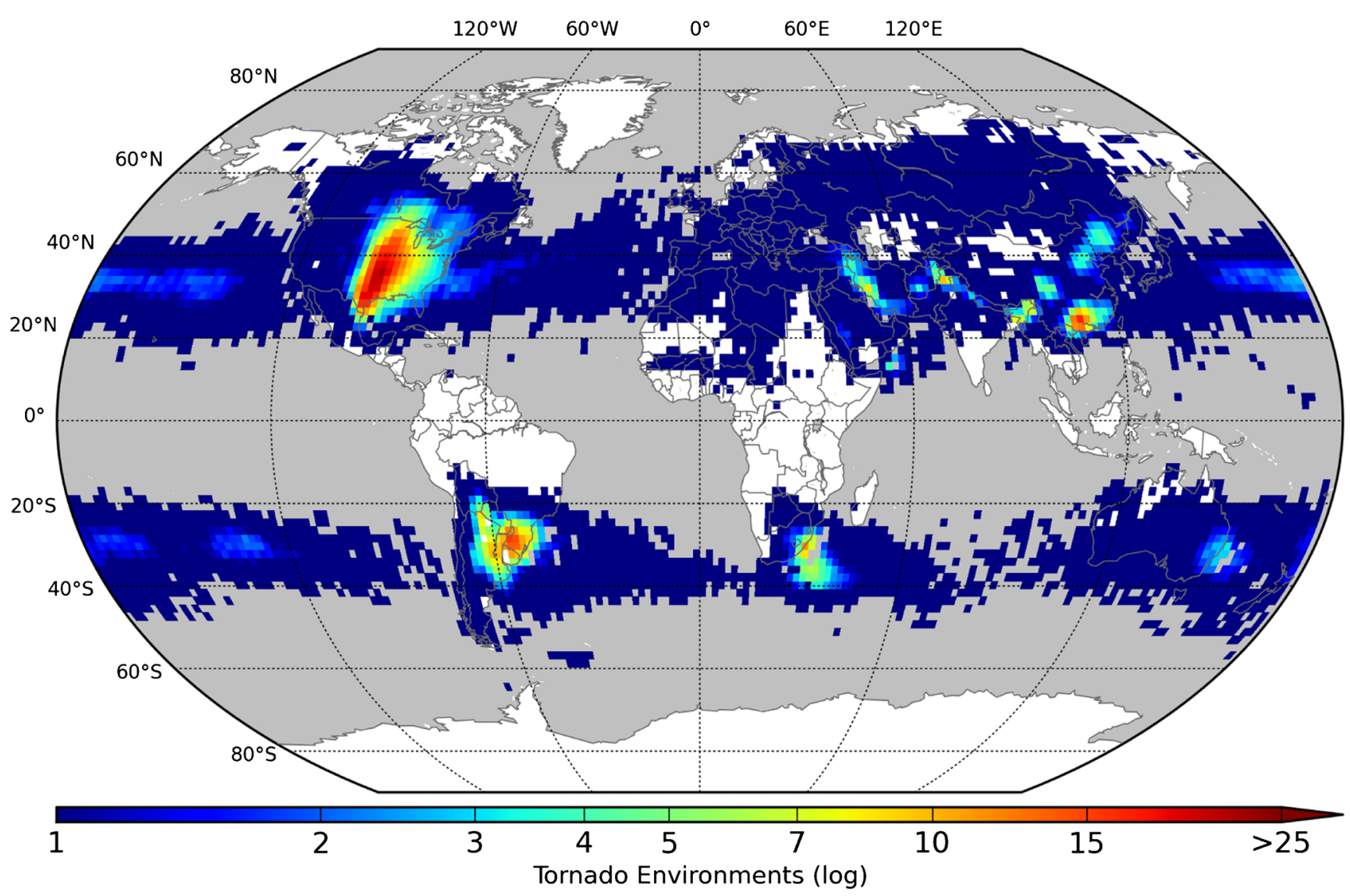

Fig. 2 Frequency of tornado environments as determined from the NCEP/NCAR reanalysis using a discriminator of $0-1 \mathrm{~km}$ bulk vertical wind shear, lifted condensation level and elevation for the period 1958-1999. Adapted from Brooks et al. [14] 
for monthly totals and for peak month. The TEI captures the overall northwest migration of tornado activity through the year (Fig. 3), but is slow to reach Kansas and Iowa and misses the late summer/fall maximum in Florida. On a regionally averaged basis, the Pearson (rank) correlation between the tornado report and TEI annual cycles exceeded $0.85(0.83)$ in all NOAA climate regions except for the Northwest and West [88].

Trapp et al. [89] downscaled 10 years (1991-2000) of NCEP/NCAR reanalysis data with resolution $(4.25 \mathrm{~km})$ adequate for explicit representation of deep convective storms and defined model HCW as those gridpoints where updraft helicity and reflectivity exceeded specified thresholds. The dynamically downscaled HCW captured some aspects of the seasonality and spatial distribution of reports, with a more pronounced northward migration during the AprilJune period than is seen in reports. An extension of this approach to the period 1990-2009 with a different proxy method yielded comparable seasonality findings [73]. Using a similar methodology, Gensini and Mote [45] found the diurnal variability and spatial variability of $\mathrm{HCW}$ during the peak of the annual cycle admirably captured via a downscaled proxy (Fig. 4).

Long and Stoy [59] used the SPC tornado report data ranging 1954-2009 to compute the climatological average day of the tornado season (which they refer to as the "peak") in the Southern and Central Great Plains. They argue plausibly that this quantity is less likely to be affected by non-meteorological trends in the total number of tornado reports and conclude that the average day of the tornado season has moved 7 days earlier over the last 60 years without a discernible change in the length of tornado season. Although no physical mechanism linking this change in seasonality to climate factors has been given, seasonality changes in some climate variables is expected with climate change [38].

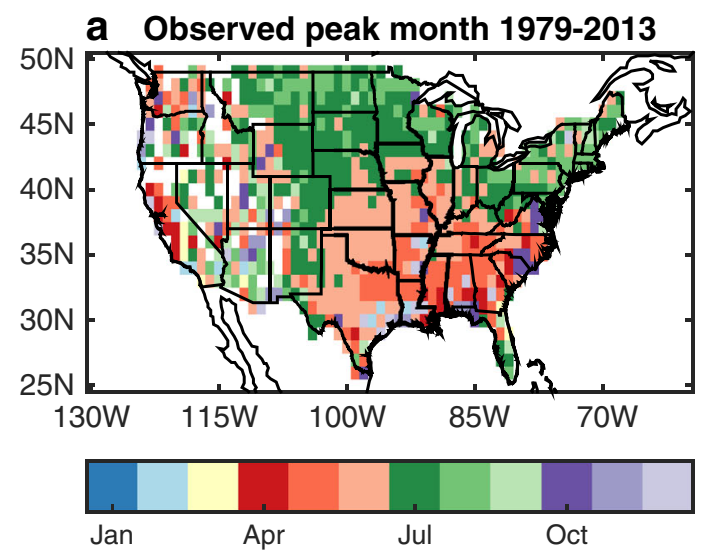

\section{Seasonal and Intraseasonal Climate Variability}

Hemispheric circulations can force synoptic-scale regimes that facilitate mesoscale processes which, in turn, can favor the development and sustenance of severe convection [25, $29,51,53]$. These circulation patterns can arise from tropical forcing or internal variability. Robust relations with HCW are generally hard to detect because the impacts of circulation signals are relatively weak compared to the variability of HCW activity, but have the potential to expand forecasts of $\mathrm{HCW}$ activity to extended range and seasonal scales.

The Madden-Julian Oscillation

Anomalous convection in the Indian Ocean is associated with the MJO (Madden and Julian [60]) and excites Rossby waves which propagate northeastward and downstream towards the USA. The dispersion of the MJO-modulated wave train can project to synoptic-scale weather regimes favorable for HCW. Recent research has related US tornado and hail activity with MJO phase and strength, as characterized by the real-time multivariate MJO indices (RMM; $[6,7$, 84, 97]). However, a consistent and robust relation between MJO phase and US HCW is not completely established; the results depend on the metric used for HCW activity as well as calendar month. Specifically, Barrett and Gensini [6] showed that phases $5 / 6$ and 8 are associated with above average tornado activity in the central USA during April and May (Fig. 5). On the other hand, Thompson and Roundy [84] found phase 2 to be associated with violent MarchMay tornado outbreak days (24-h periods during which six or more $\mathrm{EF} 2+$ tornadoes occur). While the predictability of the MJO (2-3 weeks) suggests potential for extended range predictability of $\mathrm{HCW}$ activity, further research is required [95].

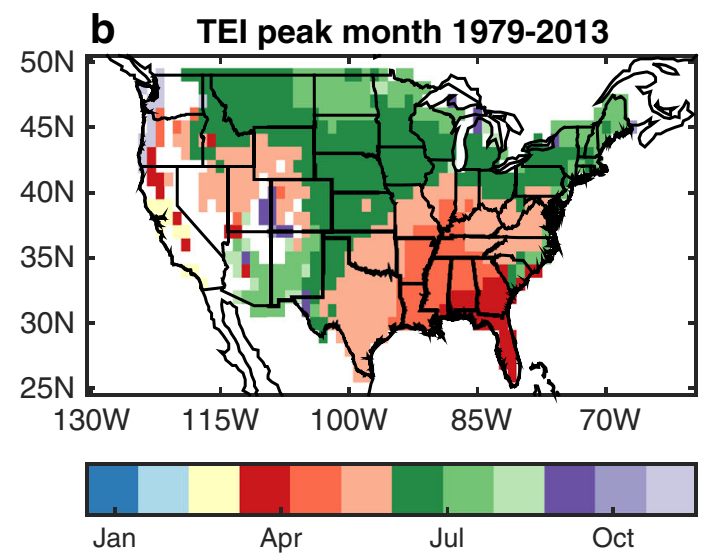

Fig. 3 Peak calendar month during the period 1979-2013 with the maximum number of tornadoes by color according to a reports and b TEI values. Adapted from Tippett et al. [87] 


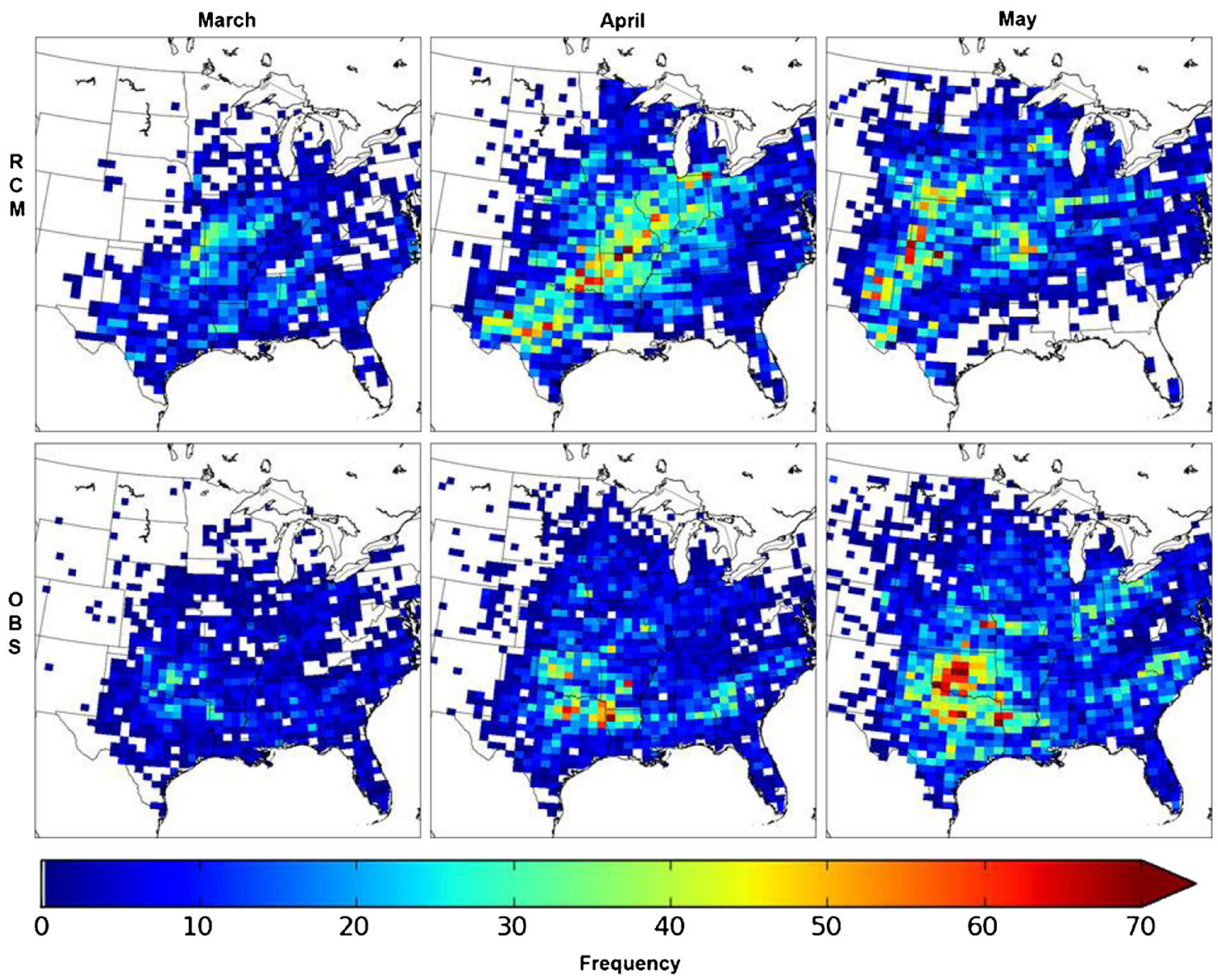

Fig. 4 Frequency of 1980-1990 March-May HCW as depicted synthetically from a RCM using dynamical downscaling (top row) and observations (bottom row). Used with permission from [45]

\section{ENSO}

ENSO modulates US precipitation and temperature via perturbations of the jet stream [75, 76]. In winter months, El Niño conditions enhance the jet stream over the Gulf Coast,

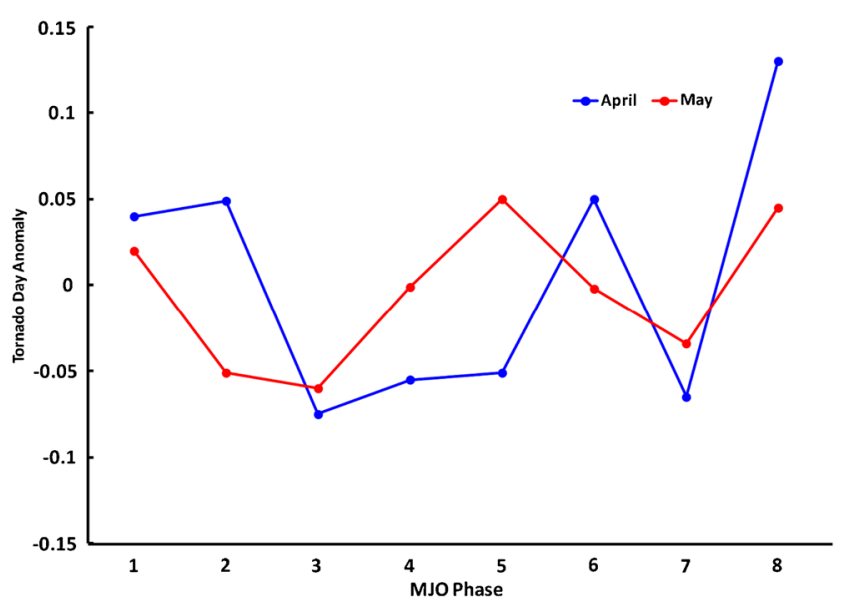

Fig. 5 Anomaly of a central US tornado day between 90 and $106 \mathrm{~W}$ by MJO phase for the period 1990-2011 [6] increasing regional tornado frequency and suppressing it over the continent. In contrast, a northwardly displaced jet during La Niña conditions increases the likelihood of tornado occurrence further north, along a band extending from Louisiana to Michigan [25, 64]. A relationship between La Niña conditions and enhanced HCW has proven difficult to demonstrate robustly for the spring season [25, 64]. While limitations of the observational record and high variability have made it difficult to demonstrate an unambiguous relation between ENSO and springtime US HWC activity, several lines of evidence are highly suggestive of enhanced HWC activity occurring during La Niña conditions. Muñoz and Enfield [67] found a rank correlation of -0.41 between the Niño 3.4 index and an index of spring (E)F2+ tornado numbers in the region of the lower Mississippi, Tennessee and Ohio River basins for the period 1950-2006. However, this regional tornado activity index has long-term trends similar to the US annual one in Fig. 1. Weaver et al. [96] correlated global SST with regional (E)F2+ and detrended (E)F0+ April-June values over the period 1950-2010. Negative SST correlations over much of the globe were found with the North Great Plains (E)F2+ index. Using April and 
May violent tornadoes (F3+), Lee et al. [57] argued that the Trans-Niño Index (TNI) was better suited to relate ENSO variability and tornado activity than Nino 3.4. Model simulations show that positive TNI conditions (characterized by colder than normal SST in the Central Pacific) are associated with enhanced moisture transport and wind shear over the southeast, conditions favorable for HCW activity. However, the relation between TNI and observed number of violent tornadoes is sensitive to outliers; when the extreme year of 1974 is removed, it is not statistically significant.

Climatologies of severe weather are relatively sparse for other continents, and thus, there are few studies of the influence of ENSO. Allen and Karoly [1] showed that the ENSO signal has a strong contribution to HCW over southeastern Australia. The relationship is dependent on changes to moisture over the continent, and thus during El Niño (dry) years, HCW frequency is reduced over the southeast, while in La Niña (wet) years, HWC frequency increases. Intriguingly, neutral years were found to have some of the highest frequencies, suggesting that other climatic signals make significant contributions. Over Brazil, no connection has yet been made for severe convection; however, there is the suggestion that that El Niño conditions promote thunderstorm occurrence [69].

\section{Large-Scale Circulation Variability}

Climate signals which modulate precipitation and drought might also be expected to have an impact on the frequency of HCW. Shepherd et al. [82] analyzed the relationship of fall/winter drought with tornado days during the subsequent spring over Northern Georgia and found that antecedent drought is correlated with a reduction in tornado days. The US drought of 2012 coincided with a low number of tornadoes, as well as lightning strikes, particularly for the positive cloud-to-ground strikes commonly associated with HCW [54]. Moisture transport and precipitation in the Mississippi, Tennessee, and Ohio River basins in early spring (March-April) are modulated by the variability of low-level winds over the Gulf of Mexico and Caribbean Sea, which are significantly correlated with the PNA and ENSO [67]. A regional index of smoothed tornado $(\mathrm{F} 2+)$ counts exhibits many of the same relations with circulation anomalies as seen for the low-level winds, and the rank correlations of the PNA and the regional tornado count index in March and April are -0.46 and -0.43 , respectively. Over the US Great Plains, the North American low-level jet (NALLJ) is associated with precipitation extremes through moisture transport, convergence, and enhanced atmospheric instability [96]. Seasonal (April-June) modes of low-level meridional wind anomalies also correlate with detrended regional tornado indices as well as CAPE, vertical wind shear, and SRH.

\section{Observed Trends and Long-Term Variability}

HCW Favorable Environments

Brooks and Dotzek [11] found a decrease from the late 1950s into the early 1970 s in the frequency of HCW favorable environments east of the Rocky Mountains in the NCEP/NCAR reanalysis, followed by an increase through the 1990s, with no significant trend for the 1958-1999 period overall. A substantial decrease in $\mathrm{HCW}$ favorable environment frequency was seen in South America. Robinson et al. [73] also found no significant trend in the regional frequency of HCW favorable environments over the USA in the NCEP/NCAR reanalysis over the period 1950-2009, consistent with the results of Gensini and Ashley [44] based on higher resolution NARR data (1980-2009). In contrast, Sander et al. [78] compared the frequency of extreme environments and large loss events, finding upward trends as well as increased variability post-1990. Recent examinations of environments favorable to hail have suggested no appreciable trends for the total frequency over the entire US continent, but with regional variations [5]. Globally, Riemann-Campe et al. [72] looked at trends in CAPE and CIN in the ERA-40 reanalysis over the period 1958-2001 and found few robust trends over the midlatitude continents relevant to $\mathrm{HCW}$. No trend is identifiable for Australia outside of the large degree of natural variability for severe thunderstorm environments (1979-2011; Allen and Karoly [1]). Dynamical downscaling to convectionpermitting resolutions where storm-scale features begin to be resolved is a promising approach that attempts to addresses the initiation problem directly. Trapp et al. [89] and Robinson et al. [73] found no statistically significant regional trends in US HCW frequency in high-resolution (4.25 km) dynamical downscaling simulations for the period 1990-2009.

\section{US Tornadoes}

Although deficiencies of the report database do not allow assessment of trends, increased variability in US tornado reports over the last decade or two has recently been noted [16, 41, 85]. This increased variability takes a number of forms: frequent monthly records (most and fewest numbers), timing of the season (early and late starts), and increasing year-to-year changes (volatility) in the number of tornado reports. Brooks et al. [16] showed a decrease in the days with one or more $(\mathrm{E}) \mathrm{F} 1$ or greater tornadoes and an increase in the days with 30 or more $(\mathrm{E}) \mathrm{F} 1$ or greater tornadoes (Fig. 6), suggesting increased clustering of tornado activity. Elsner et al. [41] presented this increase in variability as a trend, while Tippett [85] detects a shift in volatility which is well captured by the TEI (Fig. 7), 
Fig. 6 Number of days per year with at least one and more than 30 (E)F1+ tornadoes. Black circles indicate one (E)F1+ tornado, and red triangles indicate more than 30. Large dots and lines are decadal means. Taken with permission from Brooks et al. [16]
Days Per Year With At Least 1 (E)F1+ Tornado in US

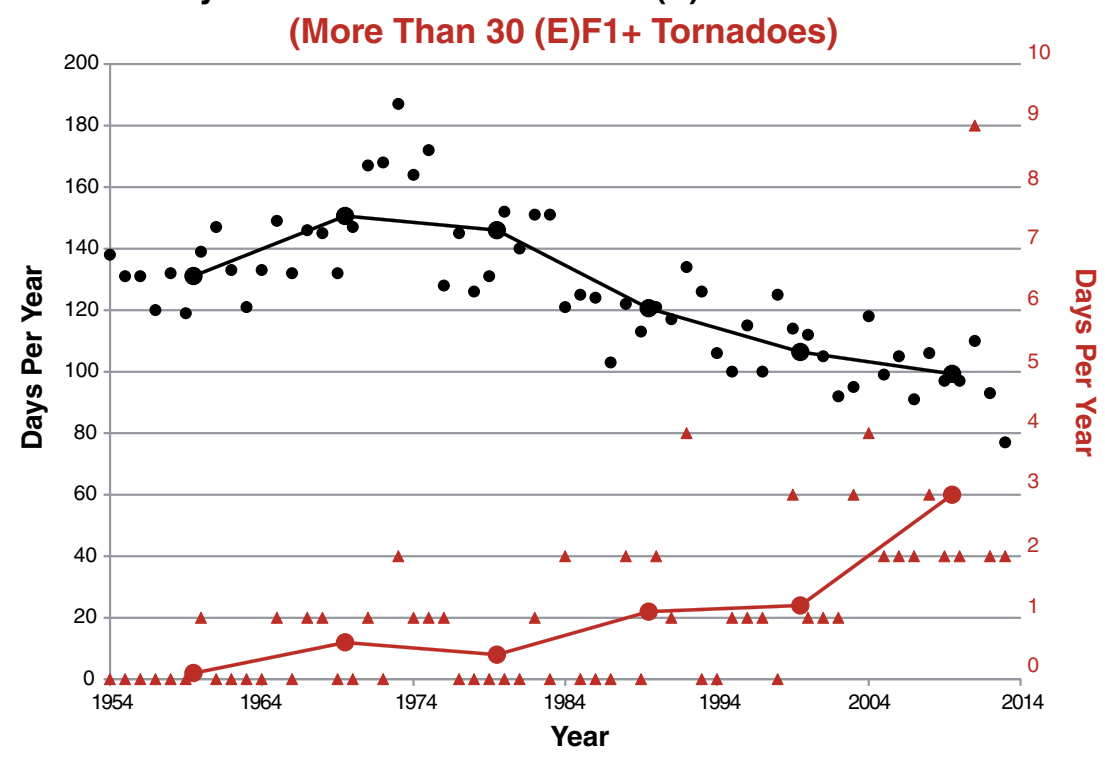

supporting the hypothesis that the changes in tornado report statistics reflect physical changes in the environment.

\section{Hail}

Analyses of trends in hail occurrence show regionally varying characteristics. US hail reports show increases associated with increasing observer density, with strong biases towards areas of larger population and road networks [5, 35]. East of the Rocky Mountains, Brooks and Dotzek [11] found strong variability in hail but no clear trend in frequency from the past 50 years. More recently, Allen et al. [5] identified a 10-fold increase in hail events for the CONUS (1979-2012) that appears to have little physical basis. In contrast, Cao [20] identified a robust upward trend in hail frequency over Ontario, Canada. Applying China's extensive hailpad network for the climate quality period (1980-2005; [98]), Xie et al. [99] found statistically significant regional decreases in observed hail frequency. For southwest Germany, Kunz et al. [56] found significant increases in both losses and number of hail days (1984-2003). This trend appears to contradict the relatively unchanged occurrence of days with thunderstorms or in losses related to flooding or wind hazard. Over the Italian Alps, non-significant decreases in hail frequency have also been observed [39]. Despite the uncertainty in a trend for Europe, southwestern France hailpad data showed a $70 \%$ increase in hail intensity for the period 1989-2009, with no significant changes to frequency [9].

Physical explanations for regional variations in hail occurrence and intensity are not simple, owing to the relatively complex microphysical processes and synoptic scale conditions that produce hail. Arguably, the two most important features are the height of the freezing level (FZL) and CAPE. Numerous studies have identified increases in FZL
Fig. 7 The year-to-year differences of CONUS tornado reports and the tornado environment index (TEI) time series. Adapted from [85]

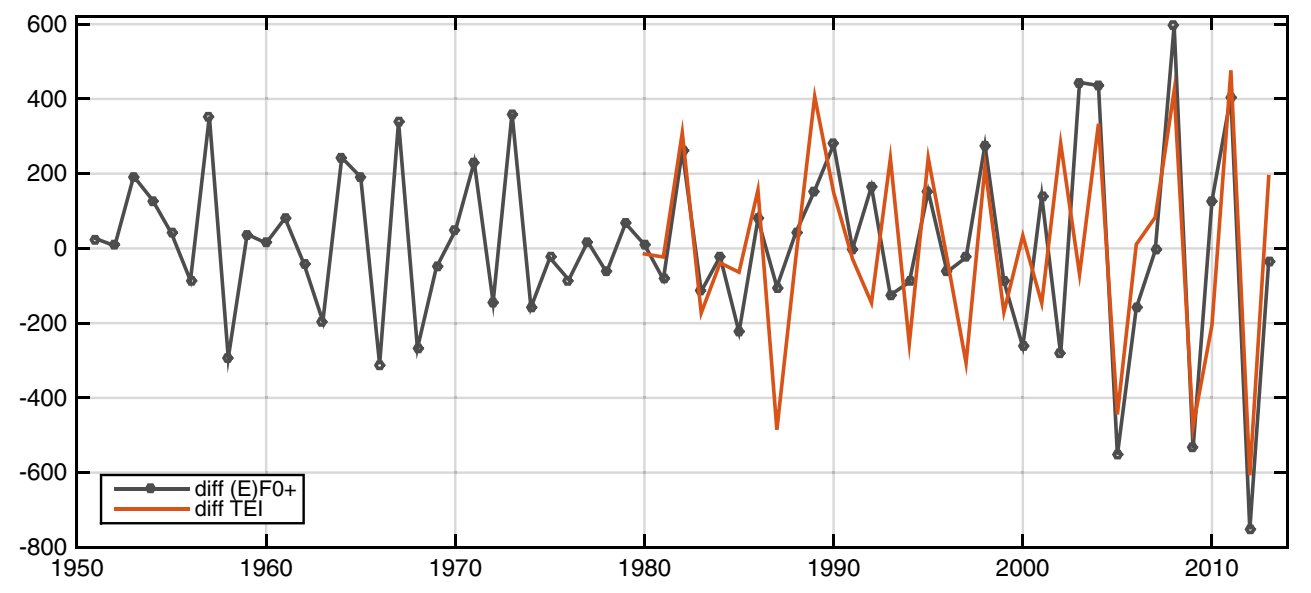


height $[66,98,99]$, which is suggested to influence melting of smaller hailstones in the atmosphere, but is not as important for stones of larger diameters for which melting is negligible [30, 61]. Surface thermodynamic energy, in contrast, has shown upward trends for China and Europe, increasing the ability of storm updrafts to support larger hailstones when combined with only small decreases in wind shear $[39,56,66,98]$. On the synoptic scale, conditions in the past two to three decades show increases on the regimes favorable to hail development [43, 53]. Questions remain regarding how hail will be influenced by the introduction of atmospheric aerosols over China, changes to available moisture sources, changes to storm organization (e.g., will supercells be as common in decreased vertical wind shear), and the regional sensitivity of hail to changes in FZL and CAPE [30, 66, 99].

\section{Lightning}

Lightning often accompanies the storms that produce HCW, though its absence does not preclude these events. However, unlike HCW, lightning can be directly detected by remote sensing. Overall, lighting is expected to increase in a warming climate [70, 74]. Villarini and Smith [94] used data from the National Lightning Detection Network over the USA to examine trends in cloud-to-ground lightning (1995-2010) and found that days with the largest number of lightning flashes are clustered at the end of the record,
Fig. 8 Response of severe thunderstorm environments in the late twenty-first century period of RCP8.5 during the winter (DJF), spring (MAM), summer (JJA), and autumn (SON) seasons. a-d Color contours show the difference in the number of days on which severe thunderstorm environments occur (NDSEV) between the 2070-2099 period of RCP8.5 and the 1970-1999 baseline calculated as 2070-2099 minus 1970-1999. Black (gray) dots identify areas where the ensemble signal exceeds one (two) SD(s) of the ensemble noise, which we refer to as robust (highly robust). $\mathbf{e - h}$ Each gray line shows an individual model realization. For each realization, the anomaly in the regional average NDSEV value over the eastern USA $\left(105-67.5^{\circ} \mathrm{W}, 25-50^{\circ} \mathrm{N}\right.$; land points only) is calculated for each year in the twenty-first century, with the anomaly expressed as a percentage of the 1970-1999 baseline mean value. A 31-year running mean then is applied to each time series of percentage anomalies. The black line shows the mean of the individual realizations. Taken with permission from

Diffenbaugh et al. [31]
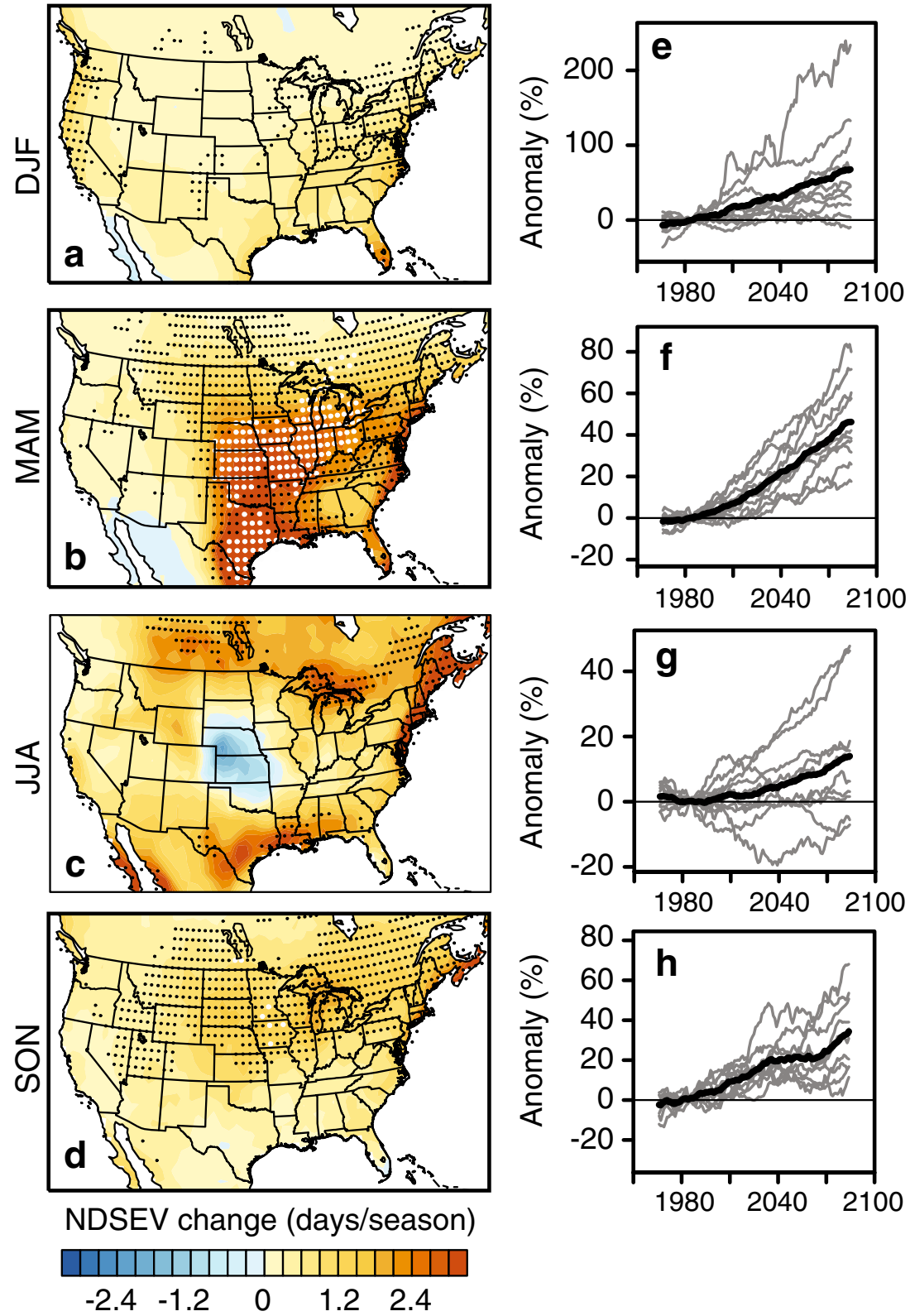
especially for positive strikes. Mostly increasing (decreasing) trends were observed in spring-summer monthly lightning activity east (west) of the Rocky Mountains, though changes in the observation system occurred during the period. On the other hand, Koshak et al. [54] found a negative trend in the total number cloud-to-ground strikes (2003-2012).

\section{Climate Change Projections}

The Intergovernmental Panel on Climate Change (IPCC) and the US Climate Change Science Program (CCSP) have provided relatively little guidance as to potential changes in the frequency and intensity of $\mathrm{HCW}$ in a future, anthropogenically altered, climate $[10,52]$. This uncertainty about future $\mathrm{HCW}$ activity reflects the poor observational record and the limited ability of climate models to resolve HCW or its environments. Climate model studies of large-scale convective environments have indicated that $\mathrm{HCW}$ activity is likely to increase in the future based on increases in CAPE which offset decreases in wind shear $[10,28,31,46,81,90$ 92]. Confidence in such projections is limited because the environment approach does not explicitly consider factors that influence storm initiation, and both GCMs and RCMs struggle to simulate basic features such as the diurnal cycle of convection [3].

Diffenbaugh et al. [31] computed the number of days with favorable severe thunderstorm environments (NDSEV) over the USA in 10 GCM CMIP5 projections (RCP 8.5). Increases in NDSEV by the end of the twenty-first century are seen in Fig. 8 in all seasons, with the largest relative increases $(50 \%)$ in winter (DJF) and the largest absolute increases ( 2 days/grid point) in spring (MAM). Robust increases in mean CAPE consistent with increases in lowlevel moisture are seen in all seasons. Robust decreases in the seasonal mean value of S06 are present in all seasons except spring (MAM) when the model projection signals show less consensus (not shown). Further confirming the results of the relatively coarse CMIP5 models, Gensini et al. [46] found severe convective environments increased across portions of the Great Lakes, Northeast USA, and
Fig. 9 Changes to Australian HCW environments determined using the weighted product of CAPE and S06 (SEV) for the period 2079-2099 in a highly warmed simulation (CMIP3 A2B) as compared to 1980-2000 from the CSIRO Mk3.6 GCM $(\mathbf{a}, \mathbf{c}, \mathbf{e})$ and the downscaled output from a similar model using the Cubic-Conformal Atmospheric Model (CCAM) $(\mathbf{b}, \mathbf{d}, \mathbf{f})$ for three segements of the Australian HCW season. Stippling is indicative of significant increases to the twenty-first century mean above the 97.5th percentile, while hatching indicatessignificant decreases below the 2.5 th percentile as determined using a bootstrapping procedure. Units are in terms of changes to the number of environments per season. Used with permission from [4]
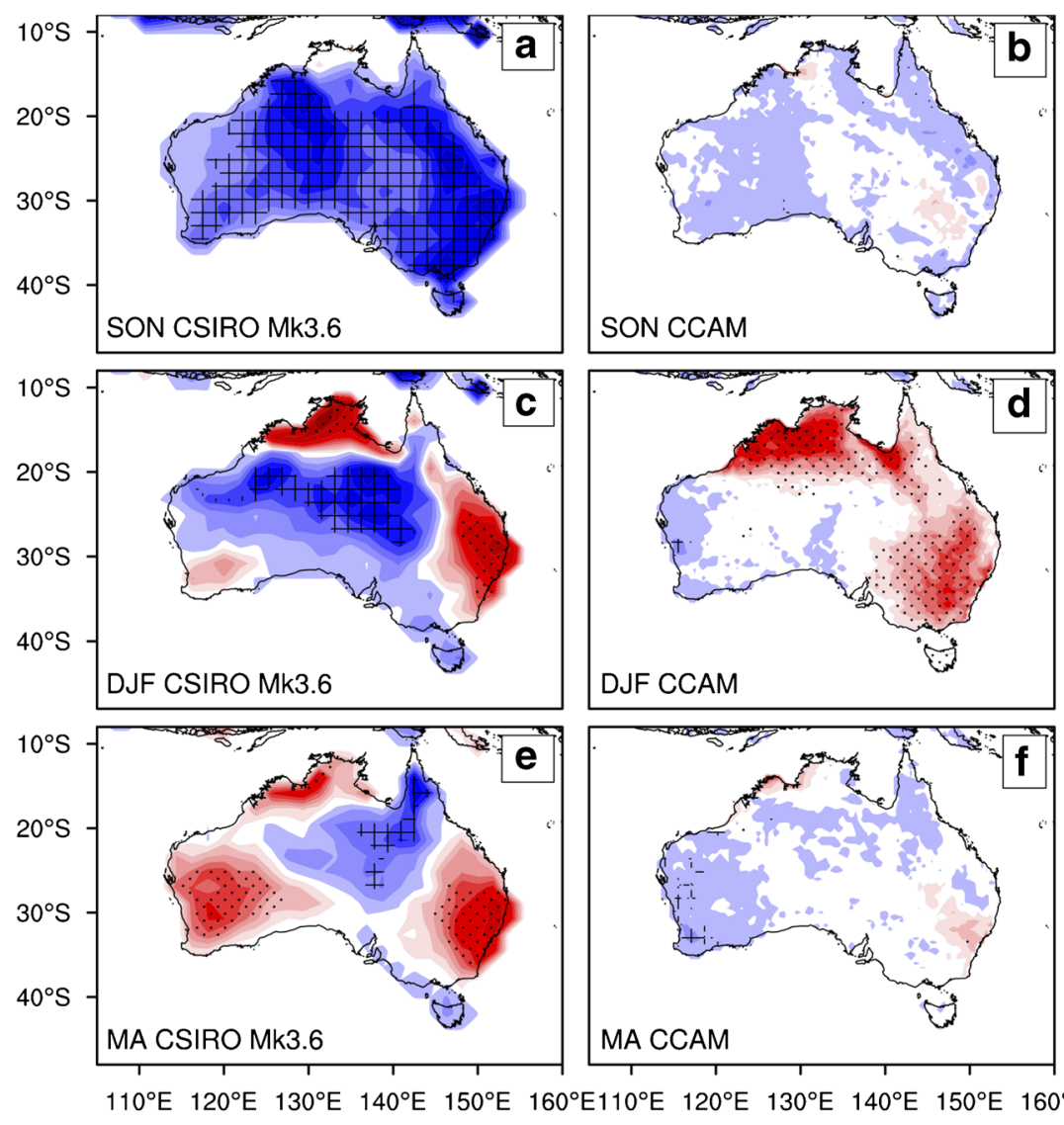

$110^{\circ} \mathrm{E} 120^{\circ} \mathrm{E} 130^{\circ} \mathrm{E} 140^{\circ} \mathrm{E} \quad 150^{\circ} \mathrm{E} \quad 160^{\circ} \mathrm{E} 110^{\circ} \mathrm{E} 120^{\circ} \mathrm{E} 130^{\circ} \mathrm{E} \quad 140^{\circ} \mathrm{E} 150^{\circ} \mathrm{E} 160^{\circ} \mathrm{E}$

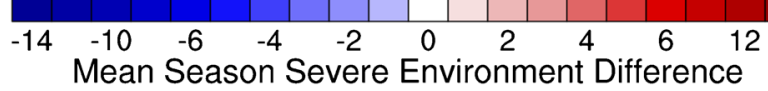


Southeast Canada during the period 2041-2065 in regional downscaling.

Over Europe, Marsh et al. [63] found that average warm season CAPE values decreased while cool season values increased in one climate change projection model. The joint behavior of CAPE and vertical shear indicated a small increase in the number of $\mathrm{HCW}$ favorable environments in the warm season. For Australia, results have been somewhat model dependent, particularly in their handling of inland moisture (e.g., [4, 68]). Recent GCM and RCM projections suggest that $\mathrm{HCW}$ will increase, particularly over the eastern third of the continent (Fig. 9), consistent with increasing CAPE, which offsets any decreases in vertical wind shear $[3,4]$.

Future projections of hail occurrence have been based on empirical relations between hail and environment as well as explicit modeling of cloud microphysics. Explicit modeling for the Sydney, Australia, basin suggests that the number of hail days will increase with increasing initiating factors though this may have some model dependencies over southeast Australia [58, 68]. Hail size, however, was projected to increase with larger CAPE [58]. Simulations using a high-resolution regional model over Colorado project a near elimination of surface hail related to the increasing melting level height, despite more intense future storms and greater in-cloud hail loading [61]. Over the UK, an empirical hail model driven by regional climate model projections has shown decreasing trends in the occurrence of hail between 15 and $50 \mathrm{~mm}$ in diameter related to decreasing CAPE and increasing freezing level [79]. Using observed relations between hail pad data and melting level, Dessens et al. [30] found that increases in melting level are expected to decrease the frequency of the smallest hailstones, but increase the frequency of larger hail stones and overall intensity by around 2040. Kapsch et al. [53] found a modest increase (7-15\%) in the frequency of weather types associated with hail over Germany by 2030-2045.

\section{Discussion and Conclusions}

The primary difficulty in relating hazardous convective weather (HCW; tornadoes, hail, and damaging winds) with large-scale climate signals is the lack of high-quality observations of HCW. There is no foreseeable solution to this problem, and current observation collection practices remain inadequate. The US HCW report database contains poorly characterized, non-physical variability in time and space which is substantially greater than that expected from climate sources. Other HCW databases have more serious deficiencies. Despite these issues with the observational record, progress has been made recently connecting HCW occurrence with the Madden-Julian Oscillation (MJO; [6, 7, 84]), El Nino-Southern Oscillation (ENSO; [57, 67]), and large-scale circulation variability [67, 96]. Recently, several authors have noted an increase in the variability of US tornado reports $[16,41,85]$. Despite indications that this change in variability is related to the large-scale environment, there is no evidence connecting it to known climate signals.

Analysis of environments favorable to HCW (e.g., CAPE and vertical wind shear) provides another avenue for relating HCW activity and climate signals. This approach is limited by the extent to which variability of environments captures actual HCW variability, though recent comparisons reveal that environments capture many aspects of the annual cycle, interannual, and multidecadal variability of $\mathrm{HCW}$ activity in the current climate $[5,85,87,88]$. The question of how the frequency of HCW has changed over the past few decades can be addressed via environments, and Sander et al. [78] found increasing trends in the frequency of the most extreme US environments over the last three decades. No trends are seen in the less extreme US environments $[11,44,73]$. Climate change projections indicate an increase in US environments over the next century favorable to HCW $[4,31,46,81]$. Understanding how environments constrain actual HCW occurrence remains a poorly answered question.

As computing resources increase, dynamical downscaling to convection-permitting resolution $(\leq 4 \mathrm{~km})$, like that used for short-range forecasting [24], becomes feasible for climate studies. This method has been used to simulate storm-scale features and infer HCW activity in the current climate $[45,73,89]$ and will likely continue to improve our understanding and confidence in projections of future $\mathrm{HCW}$ activity.

Acknowledgments This study was supported by NOAA's Climate Program Office's Modeling, Analysis, Predictions, and Projections program award NA14OAR4310185, the Office of Naval Research award N00014-12-1-091, and a Columbia University Research Initiatives for Science and Engineering (RISE) award. The views expressed herein are those of the author and do not necessarily reflect the views of NOAA or any of its sub-agencies. The authors thank Noah Diffenbaugh for providing Fig. 8.

Conflict of Interests On behalf of all authors, the corresponding author states that there is no conflict of interest.

Open Access This article is distributed under the terms of the Creative Commons Attribution License which permits any use, distribution, and reproduction in any medium, provided the original author(s) and the source are credited. 


\section{References}

1. Allen JT, Karoly DJ. A climatology of Australian severe thunderstorm environments 1979-2011: Inter-annual variability and ENSO influence. Int J Climatol. 2014;34:81-97. doi:10.1002/joc.3667.

2. Allen JT, Karoly DJ, Mills GA. A severe thunderstorm climatology for Australia and associated thunderstorm environments. Aust Meteor Oceanogr J. 2011;61:143-58.

3. Allen JT, Karoly DJ, Walsh KJ. Future Australian severe thunderstorm environments. Part I: a novel evaluation and climatology of convective parameters from two climate models for the late twentieth century. J Climate. 2014a;27:3827-47. doi:10.1175/JCLI-D-13-00425.1.

4. Allen JT, Karoly DJ, Walsh KJ. Future Australian severe thunderstorm environments. Part II: the influence of a strongly warming climate on convective environments. J Climate. 2014b;27: 3848-68. doi:10.1175/JCLI-D-13-00426.1.

5. Allen JT, Tippett MK, Sobel AH. An empirical model relating U.S. monthly hail occurrence to large-scale meteorological environment. J Adv Modelling Earth Sys. 2015. doi:10.1002/2014MS000397.

6. Barrett BS, Gensini VA. Variability of central United States April-May tornado day likelihood by phase of the Madden-Julian Oscillation. Geophys Res Lett. 2013;40:2790-5. doi:10.1002/grl.50522.

7. Barrett BS, Henley BN. Intraseasonal variability of hail in the contiguous United States: relationship to the Madden-Julian Oscillation. Mon Wea Rev. 2015. doi:10.1175/MWR-D-14-00257.1.

8. Bedka K, Brunner J, Dworak R, Feltz W, Otkin J, Greenwald T. Objective satellite-based detection of overshooting tops using infrared window channel brightness temperature gradients. J Appl Meteor Climatol. 2010;49:181-202. doi:10.1175/2009JAMC2286.1.

9. Berthet C, Dessens J, Sanchez J. Regional and yearly variations of hail frequency and intensity in France. Atmos Res. 2011;100:391-400.

10. Brooks HE. Severe thunderstorms and climate change. Atmos Res. 2013;123:129-38. doi:10.1016/j.atmosres.2012.04.002.

11. Brooks HE, Dotzek N. The spatial distribution of severe convective storms and an analysis of their secular changes. In: Diaz HF, Murnane R, editors. Climate extremes and society. New York: Cambridge University Press; 2007, pp. 35-54.

12. Brooks HE, Doswell CA III, Cooper J. On the environments of tornadic and nontornadic mesocyclones. Wea Forecasting. 1994;9:606-18

13. Brooks HE, Doswell CA III, Kay MP. Climatological estimates of local daily tornado probability for the United States. Wea Forecasting. 2003a; 18:626-40.

14. Brooks HE, Lee JW, Craven JP. The spatial distribution of severe thunderstorm and tornado environments from global reanalysis data. Atmos Res. 2003b;67-68:73-94.

15. Brooks HE, Anderson AR, Riemann K, Ebbers I, Flachs $\mathrm{H}$. Climatological aspects of convective parameters from the NCAR/NCEP reanalysis. Atmos Res. 2007;83:294-305.

16. Brooks HE, Carbin GW, Marsh PT. Increased variability of tornado occurrence in the United States. Science 2014;346: 349-52.

17. Camargo S, Tippett M, Sobel A, Vecchi G, Zhao M. Testing the performance of tropical cyclone genesis indices in future climates using the HIRAM model. J Climate. 2014. doi:10.1175/JCLI-D-13-00505.1.

18. Camargo SJ, Emanuel KA, Sobel AH. Use of a genesis potential index to diagnose ENSO effects on tropical cyclone genesis. $\mathbf{J}$ Climate. 2007;20:4819-34.
19. Camargo SJ, Wheeler MC, Sobel AH. Diagnosis of the MJO modulation of tropical cyclogenesis using an empirical index. $\mathrm{J}$ Atmos Sci. 2009;66:3061-74.

20. Cao Z. Severe hail frequency over Ontario, Canada: recent trend and variability. Geophys Res Lett. 2008;35:L14,803. doi:10.1029/2008GL034888.

21. Cecil DJ, Blankenship CB. Toward a global climatology of severe hailstorms as estimated by satellite passive microwave imagers. J Climate. 2012;25:687-703.

22. Changnon SA, Changnon D. Long-term fluctuations in hail incidences in the United States. J Climate. 2000;13:658-664.

23. Cintineo JL, Smith TM, Lakshmanan V, Brooks HE, Ortega KL. An objective high-resolution hail climatology of the contiguous United States. Wea Forecasting. 2012;27:1235-1248. doi:10.1175/WAF-D-11-00151.1.

24. Clark AJ, Weiss SJ, Kain JS, Jirak IL, Coniglio M, Melick CJ, Siewert C, Sobash RA, Marsh PT, Dean AR, Xue M, Kong F, Thomas KW, Wang Y, Brewster K, Gao J, Wang X, Du J, Novak DR, Barthold FE, Bodner MJ, Levit JJ, Entwistle CB, Jensen TL, Correia J. An overview of the 2010 Hazardous Weather Testbed Experimental Forecast Program Spring Experiment. Bull Am Meteor Soc. 2012;93:55-74. doi:10.1175/BAMS-D-11-00040.1.

25. Cook AR, Schaefer JT. The relation of El Niño-Southern Oscillation (ENSO) to winter tornado outbreaks. Mon Wea Rev. 2008;136:3121-3137. doi:10.1175/2007MWR2171.1.

26. Davies JM, Johns RH. 1993. The tornado: its structure, dynamics, prediction, and hazards, Amer. Geophys. Union, chap Some wind and instability parameters associated with strong and violent tornadoes. 1: Wind shear and helicity, pp 573-582. No. 79 in Geophys. Monogr.

27. Davies-Jones RP. Hourly helicity, instability, and EHI in forecasting supercell tornadoes. In: Preprints, 17th Conf. Severe Local Storms, AMS; 1993.

28. Del Genio AD, Yao MS, Jonas J. Will moist convection be stronger in a warmer climate? Geophys Res Lett. 2007;34:L16,703. doi:10.1029/2007GL030525.

29. Deser C. On the teleconnectivity of the Arctic Oscillation. Geophys Res Lett. 2000;27:779-82. doi:10.1029/1999GL010945.

30. Dessens J, Berthet C, Sanchez J. Change in hailstone size distributions with an increase in the melting level height. Atmos Res In Press. 2014. doi:10.1016/j.atmosres.2014.07.004.

31. Diffenbaugh NS, Scherer M, Trapp RJ. Robust increases in severe thunderstorm environments in response to greenhouse forcing. Proc Natl Acad Sci (USA). 2013;101:16,361-6. doi:10.1073/pnas.1307758110.

32. Doswell CA III. Severe convective storms-an overview. Meteorol Monogr. 2001;28(50):1-26. doi:10.1175/0065-9401-28.50.1.

33. Doswell CA III. Societal impacts of severe thunderstorms and tornadoes: lessons learned and implications for Europe. Atmos Res. 2003;67-68:135-52. doi:10.1016/S0169-8095(03)00048-6.

34. Doswell CA III, Brooks HE, Maddox RA. Flash flood forecasting: an ingredients-based methodology. Weather Forecast. 1996;11:560 81. doi:10.1175/1520-0434(1996)011<0560:FFFAIB > 2.0.CO;2.

35. Doswell CA III, Brooks HE, Kay MP. Climatological estimates of daily local nontornadic severe thunderstorm probability for the United States. Weather Forecast. 2005;20:577-95. doi:10.1175/WAF866.1.

36. Doswell CA III, Brooks HE, Dotzek N. On the implementation of the enhanced Fujita scale in the USA. Atmos Res. 2009;93: 554-63.

37. Dotzek N, Groenemeijer P, Feuerstein B, Holzer AM. Overview of ESSL's severe convective storms research using the European Severe Weather Database ESWD. Atmos Res. 2009;93:575-86. doi:10.1016/j.atmosres.2008.10.020. 
38. Dwyer JG, Biasutti M, Sobel AH. Projected changes in the seasonal cycle of surface temperature. J Climate. 2012;25:6359-74. doi:10.1175/JCLI-D-11-00741.1.

39. Eccel E, Cau P, Riemann-Campe K, Biasioli F. Quantitative hail monitoring in an alpine area: 35-year climatology and links with atmospheric variables. Int J Climatol. 2012;32:503-17.

40. Edwards R, LaDue JG, Ferree JT, Scharfenberg K, Maier C, Coulbourne WL. Tornado intensity estimation: past, present, and future. Bull Am Meteor Soc. 2013;94:641-53. doi:10.1175/ BAMS-D-11-00006.1.

41. Elsner JB, Elsner SC, Jagger TH. The increasing efficiency of tornado days in the United States. Clim Dyn. 2014:1-9. doi:10.1007/s00382-014-2277-3.

42. Emanuel KA, Nolan DS. Tropical cyclone activity and global climate. In: Proc. of 26th Conference on Hurricanes and Tropical Meteorology, American Meteorological Society, Miami; 2004, pp. $240-1$.

43. García-Ortega E, Hermida L, Hierro R, Merino A, Gascón E, Fernández-González S, Sánchez J, López L. Anomalies, trends and variability in atmospheric fields related to hailstorms in north-eastern Spain. Int J Climatol. 2014;34:3251-63. doi:10.1002/joc.3910.

44. Gensini VA, Ashley WL. Climatology of potentially severe convective environments from the North American regional reanalysis. Electronic J Severe Storms Meteor. 2011;6: $1-40$.

45. Gensini VA, Mote TL. Estimations of hazardous convective weather in the United States using dynamical downscaling. J Climate. 2014;27:6581-9.

46. Gensini VA, Ramseyer C, Mote TL. Future convective environments using NARCCAP. Int J Climatol. 2014;34:1699-705. doi:10.1002/joc.3769.

47. Gray WM. Global view of the origin of tropical disturbances and storms. Mon Wea Rev. 1968;96:669-700.

48. Gray WM. Hurricanes: their formation, structure and likely role in the tropical circulation. In: Shaw DB, editor. Meteorology over the tropical oceans, Roy. Meteor. Soc.; 1979, pp. 155-218.

49. Groenemeijer P, Kühne T. A Climatology of tornadoes in Europe: results from the European Severe Weather Database. Mon Wea Rev. 2014. doi:10.1175/MWR-D-14-00107.1.

50. Groisman PY, Knight RW, Easterling DR, Karl TR, Hegerl GC, Razuvaev VN. Trends in intense precipitation in the climate record. J Climate. 2005;18:1326-50. doi:10.1175/JCLI3339.1.

51. Higgins RW, Schubert SD. Simulations of persistent North Pacific circulation anomalies and interhemispheric teleconnections. J Atmos Sci. 1996;53:188-207. doi:10.1175/1520-046 9(1996) $053<0188$ :SOPNPC $>2.0 . C O ; 2$.

52. IPCC. Managing the risks of extreme events and disasters to advance climate change adaptation. In: Field CB, Barros V, Stocker TF, Qin D, Dokken DJ, Ebi KL, Mastrandrea MD, Mach KJ, Plattner G-K, Allen SK, Tignor M, Midgley PM, editors. A Special Report of Working Groups I and II of the Intergovernmental Panel on Climate Change. Cambridge, UK, and New York, NY, USA: Cambridge University Press; 2012, p. 582.

53. Kapsch ML, Kunz M, Vitolo R, Economou T. Long-term trends of hail-related weather types in an ensemble of regional climate models using a Bayesian approach. J Geophys Res Atmos. 2012;117:1984-2012.

54. Koshak WJ, Cummins KL, Buechler DE, Vant-Hull B, Blakeslee RJ, Williams ER, Peterson HS. Variability of CONUS lightning in 2003-2012 and associated impacts. J Appl Meteor Climatol. 2014. doi:10.1175/JAMC-D-14-0072.1. In press.

55. Kunkel KE, Karl TR, Brooks H, Kossin J, Lawrimore JH, Arndt D, Bosart L, Changnon D, Cutter SL, Doesken N, Emanuel K, Groisman PY, Katz RW, Knutson T,
O’Brien J, Paciorek CJ, Peterson TC, Redmond K, Robinson D, Trapp J, Vose R, Weaver S, Wehner M, Wolter K, Wuebbles D. Monitoring and understanding trends in extreme storms: State of knowledge. Bull Am Meteor Soc. 2012;94:499 514. doi:10.1175/BAMS-D-11-00262.1.

56. Kunz M, Sander J, Kottmeier C. Recent trends of thunderstorm and hailstorm frequency and their relation to atmospheric characteristics in southwest Germany. Int J Climatol. 2009;29:2283-97. doi:10.1002/joc. 1865 .

57. Lee SK, Atlas R, Enfield D, Wang C, Liu H. Is there an optimal ENSO pattern that enhances large-scale atmospheric processes conducive to tornado outbreaks in the United States? J Climate. 2012;26:1626-42. doi:10.1175/JCLI-D-12-00128.1.

58. Leslie LM, Leplastrier M, Buckley BW. Estimating future trends in severe hailstorms over the Sydney Basin: a climate modelling study. Atmos Res. 2008;87:37-51.

59. Long JA, Stoy PC. Peak tornado activity is occurring earlier in the heart of "tornado alley". Geophys Res Lett. 2014;41:2014GL061,385. doi:10.1002/2014GL061385.

60. Madden RA, Julian PR. Description of global-scale circulation cells in the tropics with a 40-50 day period. J Atmos Sci. 1972;29:1109-23. doi:10.1175/1520-0469(1972)029<1109:DOGSCC $>2.0 . C O ; 2$.

61. Mahoney K, Alexander MA, Thompson G, Barsugli JJ, Scott JD. Changes in hail and flood risk in high-resolution simulations over Colorado's mountains. Nat Clim Chang. 2012;2: 125-31. doi:10.1038/nclimate1344.

62. Manzato A. Hail in northeast Italy: climatology and bivariate analysis with the sounding-derived indices. J Appl Meteor Climatol. 2012;51:449-67.

63. Marsh PT, Brooks HE, Karoly DJ. Preliminary investigation into the severe thunderstorm environment of Europe simulated by the Community Climate System Model 3. Atmos Res. 2009;93: 607-18. doi:10.1016/j.atmosres.2008.09.014.

64. Marzban C, Schaefer J. The correlation between U.S. tornadoes and Pacific sea surface temperatures. Mon Wea Rev. 2001;129:884-95. doi:10.1175/1520-0493(2001)129<0884:TCBUST $>2.0 . \mathrm{CO} ; 2$.

65. McCarthy D, Schaefer J. Tornado trends over the past thirty years. In: 14th Conf. Applied Meteorology, Amer. Meteor. Soc, Seattle, WA, 3.4; 2004

66. Mohr S, Kunz M. Recent trends and variabilities of convective parameters relevant for hail events in Germany and Europe. Atmos Res. 2013;123:211-28. doi:10.1016/j.atmosres.2012.05.016.

67. Muñoz E, Enfield D. The boreal spring variability of the IntraAmericas low-level jet and its relation with precipitation and tornadoes in the eastern United States. Clim Dynam. 2011;36: 247-59. doi:10.1007/s00382-009-0688-3.

68. Niall S, Walsh K. The impact of climate change on hailstorms in southeastern Australia. Int J Climatol. 2005;25:1933-52.

69. Pinto O. Thunderstorm climatology of Brazil: ENSO and Tropical Atlantic connections. Int J Climatol. 2014. doi:10.1002/joc.4022.

70. Price CG. Lightning applications in weather and climate research. Surv Geophys. 2013;34(6):755-67.

71. Punge HJ, Bedka KM, Kunz M, Werner A. A new physically based stochastic event catalog for hail in Europe. Nat Hazards. 2014;73:1625-45. doi:10.1007/s11069-014-1161-0.

72. Riemann-Campe K, Fraedrich K, Lunkeit F. Global climatology of Convective Available Potential Energy (CAPE) and convective inhibition (CIN) in ERA-40 reanalysis. Atmos Res. 2009;93: 534-45. doi:10.1016/j.atmosres.2008.09.037.

73. Robinson ED, Trapp RJ, Baldwin ME. The geospatial and temporal distributions of severe thunderstorms from high-resolution dynamical downscaling. J Appl Meteor Climatol. 2013;52: 2147-61. doi:10.1175/JAMC-D-12-0131.1. 
74. Romps DM, Seeley JT, Vollaro D, Molinari J. Projected increase in lightning strikes in the united states due to global warming. Science 2014;346:851-4.

75. Ropelewski CF, Halpert MS. North American precipitation and temperature patterns associated with the El Niño/Southern Oscillation (ENSO). Mon Wea Rev. 1986;114:2352-62.

76. Ropelewski CF, Halpert MS. Global and regional scale precipitation patterns associated with the El Niño/Southern Oscillation. Mon Wea Rev. 1987;115:1606-26.

77. Sánchez JL, Gil-Robles B, Dessens J, Martin E, Lopez L, Marcos JL, Berthet C, Fernández JT, García-Ortega E. Characterization of hailstone size spectra in hailpad networks in France, Spain, and Argentina. Atmos Res. 2009;93:641-54. doi:10.1016/j.atmosres.2008.09.033.

78. Sander J, Eichner JF, Faust E, Steuer M. Rising variability in thunderstorm-related U.S. losses as a reflection of changes in large-scale thunderstorm forcing. Wea Climate Soc. 2013;5: 317-31. doi:10.1175/WCAS-D-12-00023.1.

79. Sanderson M, Hand W, Groenemeijer P, Boorman P, Webb J, McColl L. Projected changes in hailstorms during the 21st century over the UK. Int J Climatol. 2014. doi:10.1002/joc.3958. In Press.

80. Schaefer JT, Edwards R. The SPC Tornado/Severe Thunderstorm Database. Preprints, 11th Conf. Applied Climatology, Amer Meteor Soc, Dallas; 1999, pp. 215-20.

81. Seeley JT, Romps DM. The effect of global warming on severe thunderstorms in the United States. J Climate. 2015. doi:10.1175/JCLI-D-14-00382.1.

82. Shepherd M, Niyogi D, Mote T. A seasonal-scale climatological analysis correlating spring tornadic activity with antecedent fall-winter drought in the Southeastern United States. Environ Res Lett. 2009;4:024,012. doi:10.1088/1748-9326/4/2/024012.

83. Simmons K, Sutter D. Economic and societal impacts of tornadoes. Am Meteorol Soc. 2011. doi:10.1007/978-1-935704-02-7_2.

84. Thompson DB, Roundy PE. The relationship between the Madden-Julian oscillation and U.S. violent tornado outbreaks in the spring. Mon Wea Rev. 2013;141:2087-95. doi:10.1175/MWR-D-12-00173.1.

85. Tippett MK. Changing volatility of U.S. annual tornado reports. Geophys Res Lett. 2014;41:6956-61. doi:10.1002/2014 GL061347.

86. Tippett MK, Camargo SJ, Sobel AH. A Poisson regression index for tropical cyclone genesis and the role of large-scale vorticity in genesis. J Climate. 2011;24:2335-57.
87. Tippett MK, Sobel AH, Camargo SJ. Association of U.S. tornado occurrence with monthly environmental parameters. Geophys Res Lett. 2012:39. doi:10.1029/2011GL050368.

88. Tippett MK, Sobel AH, Camargo SJ, Allen JT. An empirical relation between U.S. tornado activity and monthly environmental parameters. J Climate. 2014;27:2983-99. doi:10.1175/JCLI-D-13-00345.1.

89. Trapp R, Robinson E, Baldwin M, Diffenbaugh N, Schwedler BJ. Regional climate of hazardous convective weather through high-resolution dynamical downscaling. Clim Dyn. 2011;37: 677-88. doi:10.1007/s00382-010-0826-y.

90. Trapp RJ, Diffenbaugh NS, Brooks HE, Baldwin ME, Robinson ED, Pal JS. Changes in severe thunderstorm environment frequency during the 21 st century caused by anthropogenically enhanced global radiative forcing. Proc Natl Acad Sci (USA). 2007;104:19,719-23.

91. Trapp RJ, Diffenbaugh NS, Gluhovsky A. Transient response of severe thunderstorm forcing to elevated greenhouse gas concentrations. Geophys Res Lett. 2009:36. doi:10.1029/2008GL036203.

92. Van Klooster SL, Roebber PJ. Surface-based convective potential in the contiguous United States in a business-as-usual future climate. J Climate. 2009;22:3317-30. doi:10.1175/2009JCLI2697.1.

93. Verbout SM, Brooks HE, Leslie LM, Schultz DM. Evolution of the U.S. Tornado database: 1954-2003. Weather Forecast. 2006;21:86-93.

94. Villarini G, Smith JA. Spatial and temporal variability of cloud-to-ground lightning over the continental U.S. during the period 1995-2010. Atmos Res. 2013;124:137-48. doi:10.1016/j.atmosres.2012.12.017.

95. Wang W, Hung MP, Weaver S, Kumar A, Fu X. MJO prediction in the NCEP Climate Forecast System version 2. Clim Dyn. 2014;42:2509-20. doi:10.1007/s00382-013-1806-9.

96. Weaver SJ, Baxter S, Kumar A. Climatic role of North American low-level jets on U.S. regional tornado activity. J Climate. 2012;25:6666-83. doi:10.1175/JCLI-D-11-00568.1.

97. Wheeler MC, Hendon H. An all-season real-time multivariate MJO index: development of an index for monitoring and prediction. Mon Wea Rev. 2004;132:1917-32.

98. Xie B, Zhang Q, Wang Y. Trends in hail in China during 19602005. Geophys Res Lett. 2008;35. doi:10.1029/2008GL034067.

99. Xie B, Zhang Q, Wang Y. Observed characteristics of hail size in four regions in China during 1980-2005. J Climate. 2010;23:4973-82. 